\title{
KRAŠTOVAIZDŽIO VIZUALINĖS RAIŠKOS SAVITUMO APSAUGA DIDMIESČIO PRIEMIESTINĖSE TERITORIJOSE
}

\author{
Giedrè I. Laukaitytè-Malžinskienè \\ Urbanistikos katedra, Vilniaus Gedimino technikos universitetas, \\ Pylimo g. 26/Trakug. 1, LT-01132 Vilnius, Lietuva \\ El.paštasurbkat@ar.vgtu.lt \\ Iteikta 20080407
}

Santrauka. Didmiesčių urbanistinės plètros sąlygomis priemiesčio teritorijų kraštovaizdžio vizualinės raiškos individualumo išsaugojimas tampa aktualiu, bet sunkiai sprendžiamu uždaviniu. Teritorijų planavimo praktikoje vertinant kraštovaizdį dažniausiai apsiribojama tik bendrinių kraštovaizdžio fizinių ar regimụjų savybių aprašymu. Užstatymo pletra priemiesčio zonose paprastai remiasi tik funkciniais ir struktūriniais planavimo kriterijais. Lietuvos teritorijų planavimo teorijoje ir praktikoje pasigendama kraštovaizdžio bei užstatymo plètros vertinimo metodo, kuris būtų orientuotas ị integruotą kraštovaizdžio vertinimą bei planavimą, paremtą kraštovaizdžio fizinių, regimųjų savybių savita, žmogaus suvokiama vizualine raiška.

Reikšminiai žodžiai: urbanistinè plètra, priemiestis, kraštovaizdžio charakteris, jautrumas, suvokimas ir vizualinė raiška.

\section{Ivadas}

Pastarąji dešimtmetị urbanizacija Lietuvoje pasižymi išorine didmiesčių ekspansija - priemiesčio teritorijų metropolizacija (Juškevičius 2007, Tiškus 2007). Intensyvios urbanistinès pletros sąlygomis šių teritorijų kraštovaizdžio vizualinès raiškos individualumo išsaugojimas tampa aktualiu, bet sunkiai sprendžiamu uždaviniu. Teritorijų planavimo praktikoje vertinant kraštovaizdị dažniausiai apsiribojama tik bendriniu kraštovaizdžio fizinių ar regimųjų savybių aprašymu (LR kraštovaizdžio... 2006, Devinduonis et al. 1980). Gamtiniu požiūriu teritorija klasifikuojama pagal atskirų jos elementų homogeniškumą. Fizinių ar regimųjų kraštovaizdžio savybių inventorizacija pati savaime neturi didelio praktinio pritaikomumo, nes yra indiferentiška teritorijos kompozicinès raiškos potencialo požiūriu, tačiau kiekvienas konkretus kraštovaizdis pasižymi savita vizualine raiška, o ji susijusi su žmogaus suvokimu (Daniel, Vining 1983, Fisher et al. 1984, Kaplan R., Kaplan S. 1989, Antrop 2000, Palmer 2003). Be to, užstatymo plètra kraštovaizdyje paprastai remiasi tik funkciniais ar struktūriniais planavimo kriterijais (Jakaitis 2001, Vanagas 1991). Deja, vien tik šie kriterijai planuojant kraštovaizdi (ypač kontrastingo reljefo bei jo formų zonose) nenusako visos jo apimties - kompozicinès visumos. Užsienyje priemiesčio teritorijų pla- navimo praktikoje įtraukiami nauji - estetiniai - užstatymo plètros aspektai, tokie kaip kraštovaizdžio reprezentatyvumas, išraiškingumas, integruojant juos į ekologinių, socialinių bei kultūrinių problemų priemiestyje sprendimą (Antrop 2000, Ahern 1995, Punter, Carmona 1997, Antrop 1997). Darniosios pletros ir kraštovaizdžio kokybès siekiamybès kontekste nebeužtenka apsiriboti vienpusiu miesto, kaimo ar gamtinio kraštovaizdžio vertinimu. Priemiestis yra ta teritorija, kurioje realiai atsiskleidžia užstatymo ir gamtinès kraštovaizdžio raiškos sąveikos problematika. Šios priežastys skatina kraštovaizdžio vizualinès raiškos klasifikavimo būdu, papildančiu susiformavusia fizinių-geografiniu vienetu, išskyrimo teritorijoje sistema ir integraliu planavimo kriteriju, kaip papildomu planavimo priemoniu nustatymo paieškas, tinkamas intensyvios priemiesčio urbanizacijos arealuose, tapusias šio straipsnio tikslu.

\section{Kraštovaizdžio samprata}

Pagrindiniuose anglų kalbos žodynuose bei kraštovaizdžio politikos dokumentuose pateikiami šie kraštovaizdžio sąvokos apibrěžimai: „teritorijos ar jos dalies vaizdas“ (The Oxford... 1962), „teritorijos vaizdas“ (Oxford... 1980). „Kraštovaizdis - tai žmonių 
suvokiama vietovè, kurios pobūdị nulèmè gamtiniai ir (arba) antropogeniniai veiksniai ir jų sąveika" (The European... 2000). „Kraštovaizdis - žemès paviršiaus gamtinių (paviršinių uolienų ir reljefo, pažemio oro, paviršinių ir gruntinių vandenų, dirvožemio, gyvụjų organizmų) ir (ar) antropogeninių (archeologinių liekanų, statinių, inžinerinių įrenginių, žemès naudmenų ir informacinio lauko) komponentų, susijusių medžiaginiais, energiniais ir informaciniais ryšiais, teritorinis junginys. Tai žmonių suvokiama vietovė (teritorija), kurios pobūdį nulèmé gamtiniai ir (ar) antropogeniniai veiksniai ir jų sąveika" (LR kraštovaizdžio politikos... 2004). Pateiktuose kraštovaizdžio sąvokos aiškinimuose galima įžvelgti tris sąvokos apibrèžimo reikšminius žodžius: teritorija - kaip gamtinių ir antropogeninių komponentų darinys, vaizdas - kaip regimoji teritorijos išraiška, suvokimas -kaip galima kraštovaizdžio interpretacija. Autore straipsnyje remiasi kraštovaizdžio termino aiškinimu, kuris apima tiek fizinị, regimajji kraštovaizdžio turini, tiek jo suvokimą. Kraštovaizdžio kokybė analizuojama dažniausiai dèl dvieju priežasčių. Pirmoji - siekiant išsiaiškinti, ką žmonès vertina kraštovaizdyje, antroji - kodèl jie vertina tam tikrą kraštovaizdị. Ilgą laiką filosofai nagrinèjo, bandè nustatyti, ar kraštovaizdžio grožis glūdi pačiame kraštovaizdyje, jo bruožuose (objektyviai), ar žmoguje, kuris suvokia kraštovaizdi (subjektyviai). XVIII a. pabaigoje subjektyvusis požiūris pralenkè objektyvujj. Šiandien pažangūs mokslininkai pripažista, kad kraštovaizdžio vizualinès raiškos estetinè kokybė yra kraštovaizdžio fizinių, regimųjų savybių ir kraštovaizdžio suvokimo kompleksinis rezultatas (Daniel, Vining 1983, Fisher et al. 1984, Kaplan R., Kaplan S. 1989, Antrop 2000, Palmer 2003, Richard 1987). Anot A. Lothian'o, kraštovaizdžio kokybe pati savaime yra nieko verta, kol ji nesuvokiama kaip išlikimas. Būtent išlikimas sustiprina kraštovaizdžio kokybę, tokiu atveju kraštovaizdžio kokybè yra žmoniu suvokiama kraštovaizdžio kokybè, bet ne prigimtinė kraštovaizdžio kokybė (Lothian 2000).

Toks požiūris, autorès nuomone, yra orientuotas i kraštovaizdžio vertinimo ir planavimo prasmingumą, individualumą. Remiantis teorinių ir praktinių literatūros šaltinių studija (Landscape Character... 2002, Krause 2001, Cambridge Green... 2002, Smith 1997, Яргина 1991, Lynch 1960), galima daryti išvadą, kad pozityvus kraštovaizdžio suvokimas yra orientuotas ị konkrečią vietą, priklausomybès, prisirišimo prie jos jausmą, genius loci. Tokiu atveju kraštovaizdžio vizualinès raiškos savitumo atskleidimas ir jos išryškinimas yra išeities pozicija darniam teritorijų planavimui.

\section{Kraštovaizdžio architektūros disciplinos reikšmė}

Vienu sakiniu apibrežti kraštovaizdžio architektūros, kaip profesijos, veiklos sferą yra sunkus uždavinys. Laikui bègant šios veiklos kryptys labai išsiplètè: nuo privačių sodų iki miesto visuomeninių erdvių projektavimo, miestų ir rajonų kraštovaizdžio planavimo. XX amžiaus miestų aplinkosauginių problemų kontekste kraštovaizdžio architektūros disciplina ypač išsiplètè. Postmodernizmo laikotarpio atstovams būdingas sisteminis požiūris ị aplinką (Meyer 2000). Vèlyvajame modernizme vyravusią ryškią takoskyrą tarp gamtosaugos mokslo ir kraštovaizdžio architektūrinio projektavimo meno keičia kompleksinis požiūris ị ekologiją ir estetiką. Regioniniai ir vietos savitumai priešpastatomi universalumui, idealumui. Kraštovaizdis tampa pagrindiniu fokusu, kuriame kraštovaizdžio specialistų pagalba atsiskleidžia vietovès gamtinès, kultūrinès ir estetinès vertybès. Pagrindiniuose anglų kalbos žodynuose pateiktos šios kraštovaizdžio architektūros, kaip disciplinos, ar kraštovaizdžio architekto profesijos sampratos: „Kraštovaizdžio architektas - asmuo, kurio darbas yra planuoti bei projektuoti aplinką, pavyzdžiui, kelius, pastatus ir pan., patraukliai priderinant juos kraštovaizdyje“ (Oxford Advanced... 2005), ,kraštovaizdžio architektūra - vaizdingas teritorijos formavimas, panaudojant gamtinius elementus (Oxford American... 1980), „kraštovaizdžio formavimas - tai teritorijos išorinio vaizdo keitimas (dažniausiai pastatų ar kelių prieigose) natūralaus kraštovaizdžio link" (Cambridge... 1995), „kraštovaizdžio architektas - asmuo, kuris formuoja kraštovaizdį“, o „kraštovaizdžio architektūra - dideliụ teritorijų planavimas, išlaikant gamtinị kraštovaizdžio pobūdį" (The Oxford Modern). Taigi apibendrinant galima teigti, kad kraštovaizdžio architekto misija yra suvokti vietos ypatumus, konteksta ir suteikti forma, estetinę išraiška gamtiniams bei kultūriniams procesams kraštovaizdyje. Anot Elizabeth K. Meyer, šiuo metu daugiausia dèmesio turètų būti skiriama tiems kraštovaizdžio architektūros srities pavyzdžiams, kurie reprezentuoja naują profesijos praktiką, kai gamtiniai procesai igauna vizualiniu požiūriu raiškią ir aiškią formą, taip pat prasmingą formą tiems, kurie gyvena, dirba ar ilsisi kraštovaizdyje (Meyer 2000).

\section{Kraštovaizdžio charakterio koncepcija užsienio šalių kraštovaizdžio praktinio planavimo darbuose}

Šiuo metu kraštovaizdžio charakterio koncepcija yra vyraujanti kraštovaizdžio vertinimo ir planavimo kryptis Europoje (Landscape... 2002, Krause 2001, Cambridge 
Green... 2002, Smith 1997, Яргина 1991, Lynch 1960). Kraštovaizdžio charakterio tyrimas remiasi holistine kraštovaizdžio samprata, kai tarpusavyje siejami fiziniai, vizualiniai, estetiniai ir kraštovaizdžio suvokimo aspektai. Remiantis praktiniais kraštovaizdžio vertinimo ir planavimo pavyzdžiais išskiriamos šios esminès kraštovaizdžio charakterio vertinimo procedūros sudedamosios dalys: kraštovaizdžio charakterio tyrimas ir jo formavimo sprendiniai (Landscape... 2002, The LANDMAP... 2001, Landscape Assessment... 2006, Landscape Character... 2006). Pagrindinis kraštovaizdžio charakterio tyrimo tikslas - nustatyti bendrinius kraštovaizdžio tipus ir individualios kraštovaizdžio raiškos vietoves. Atlikus fizinių (gamtinių ir kultūrinių) kraštovaizdžio elementų analizę, išskiriami bendriniai kraštovaizdžio vienetai, pasižymintys homogenišku kraštovaizdžio pobūdžiu. Bendriniai kraštovaizdžio tipai pavadinami bendriniais pavadinimais. Visose nagrinètose šalyse šalia bendrinių kraštovaizdžio tipų papildomai išskiriami individualios kraštovaizdžio raiškos vienetai, remiantis tik konkrečiai vietai būdingomis fizinèmis, vizualinemmis ar mentalinio kraštovaizdžio suvokimo savybėmis. Anglijoje ir Škotijoje (Landscape... 2002) individualios kraštovaizdžio raiškos vietovès yra savitų gamtinių, kultūrinių savybių ar savitos vizualinès raiškos ir specifinès geografinès lokacijos vienetai konkrečiame fiziniame, t. y. bendriniame vienete, kurio pavadinimas susijęs su jo geografine vietove. Panašiai yra ir Velse (The LANDMAP... 2001). Anglijoje, Škotijoje šalia individualios kraštovaizdžio raiškos vienetų plano pridedami konkrečių vienetų pagrindinių požymių, formuojančių kraštovaizdžio charakterị, aprašai, nenustatant konkrečių elementų ar požymių vertès. Airijoje (Landscape Assessment... 2002, Landscape Character... 2006) individualios kraštovaizdžio raiškos vienetų išskyrimas išplaukia iš kraštovaizdžio vizualinių charakteristikų bei kraštovaizdžio įvaizdžio objektų. Remiantis kraštovaizdžio apžvelgiamumu išskiriami vizualiniai kraštovaizdžio vienetai, dažnu atveju apimantys net kelis bendrinius fizinius kraštovaizdžio vienetus. Būna atvejų, kai konkrečiame fiziniame vienete galima išskirti vizualinị vienetą, daugiausia nulemtą topografinių formantų, bet vis dar pasižymintį fizinio charakterio vientisumu. Taigi vienu atveju turime kompleksinį fizinị-vizualinị individualios kraštovaizdžio raiškos vienetą, kitu - fiziniu požiūriu homogenišką vienetą, kurio individualumą lemia jo pozicija erdvinèje kraštovaizdžio struktūroje. Vizualinių vienetų, kaip potencialių individualios kraštovaizdžio raiškos vienetų, išskyrimas ypač aktualus esant kalvotam reljefui. Lygaus reljefo vizualinių vienetų išskyrimas nėra toks aktualus, nes dažniausiai fiziniu požiūriu homogeniškas kraštovaizdžio charakteris prasitęsia už vizualinio vieneto ribų. Tokiu atveju išskiriant individualios kraštovaizdžio raiškos vienetus labiausiai vadovaujamasi fiziniais vietos ypatumais, išskirtinumais. Kadangi vizualinių vienetų išskyrimas daugiausia remiasi natūriniais tyrimais, šio pobūdžio vienetų išskyrimas Airijos praktikos pavyzdžiu dažniausiai taikomas dirbant su smulkesniu masteliu. Anglijos, Škotijos ir Velso kraštovaizdžio charakterio vertinimo pavyzdžiuose, nors ir atliekama vizualinè kraštovaizdžio analizė, apsiribojama fizinio, t. y. bendrinio kraštovaizdžio vieneto ribų nustatymu. Kraštovaizdžio įvaizdžio vienetai Airijoje taip pat pajègūs tapti individualios kraštovaizdžio raiškos vietovèmis. Dažniausiai patị ịvaizdị formuoja konktretus gamtinis ar kultūrinis elementas kaip pagrindinis vietos orientyras, jo vizualinès ịtakos riba ir nulemia įvaizdžio vieneto ribas (Landscape Character... 2006).

Antroji, taip pat svarbi kraštovaizdžio charakterio vertinimo dalis - kraštovaizdžio formavimo sprendinių. Anglijoje ir Škotijoje (Landscape... 2002) kraštovaizdžio sprendiniai remiasi žiniomis apie kraštovaizdžio charakterí, bet ne kraštovaizdžio verte. Šiuo atveju kraštovaizdžio charakterio vertinimo esmè - urbanistinès plètros planavimas konkrečioje vietoveje. Todèl šių šalių praktikoje tik tolesniame kraštovaizdžio vertinimo etape sprendiniai diferencijuojami, atsižvelgiant $\mathfrak{i}$ konkrečius planavimo tikslus: kraštovaizdžio esamos būklès kokybès, kraštovaizdžio vertès, kraštovaizdžio jautrumo bei kraštovaizdžio talpumo nustatymą. Kraštovaizdžio vertė nustatoma turint tikslą suteikti teritorijai tam tikrą statusą. Kraštovaizdžio jautrumas galimai užstatymo plètrai remiasi kraštovaizdžio charakterio jautrumu. Anglijos ir Škotijos atveju nustatant kraštovaizdžio charakterio jautrumą daugiausia demesio skiriama kraštovaizdžio charakterio savybėms, o Velse ir Airijoje (The LANDMAP... 2001, Landscape Character... 2006) kraštovaizdžio sprendiniai labiau orientuoti $\mathfrak{i}$ kraštovaizdžio vertingumą. Velse LANDMAP daugiausia dèmesio skiriama kraštovaizdžio kokybei įvertinti. Kraštovaizdžio kokybès iqvertinimo koncepcija - centrine LANDMAP mintis. Toks požiūris grịstas tuo, kad, norint priimti konkrečius sprendimus apie kraštovaizdžio pokyčius, būtina ịvertinti kiekvieną galimybę dèl tų vertybių, kuriomis jis pasižymi. Šiuo atveju kraštovaizdis pagal vertingumą suskirstomas i didžiausios, vidutinès bei mažiausios kraštovaizdžio vertès teritorijas. Tačiau, vadovaujantis tik abstrakčiomis kraštovaizdžio vertès 
kategorijomis, nustatomos teritorijų tolerancijos galimai plètrai kategorijos praktiškai praranda tiesiogini ryši su kraštovaizdžio elementais, jų savybemis. Airijos (taip pat ir Velso pavyzdžiu) kraštovaizdžio vertybių nustatymas rengiant kraštovaizdžio formavimo sprendinius užima svarbią vietą. Daug dèmesio skiriama ne tiesiogiai kraštovaizdžio elementams ar savybèms, bet kraštovaizdžio poveikiui, gamtinèms, kultūrinèms ar estetinèms funkcijoms, kuriomis jis pasižymi. Šiuo atveju kraštovaizdžio gamtinès, kultūrinès bei estetinès funkcijos ir yra vertybès, kuriomis reikia rūpintis, jas saugoti. Kraštovaizdžio elementai yra kokybiško kraštovaizdžio funkcionavimo pagrindas. Taigi funkcinès kraštovaizdžio vertybès ir ịvertintas jų jautrumas konkrečiose individualios kraštovaizdžio raiškos vietovèse yra pagrindas ir išeities pozicija plètros galimybèms nustatyti, teritorijų jautrumo galimai plètrai apibrěžti. Faktineje situacijoje planuotojams suteikiama nepakankamai informacijos apie kraštovaizdžio charakteri, jo fizinius ar vizualinius ypatumus. Net ir mažo intensyvumo plètrai reiketu respektuoti kraštovaizdžio charakteri, nes ne visuomet tai, kas vertinga, yra jautru (Landscape... 2002).

Autorès nuomone, reikšmingiausias kraštovaizdžio charakterio vertinimo rezultatas yra konkrečios vietos

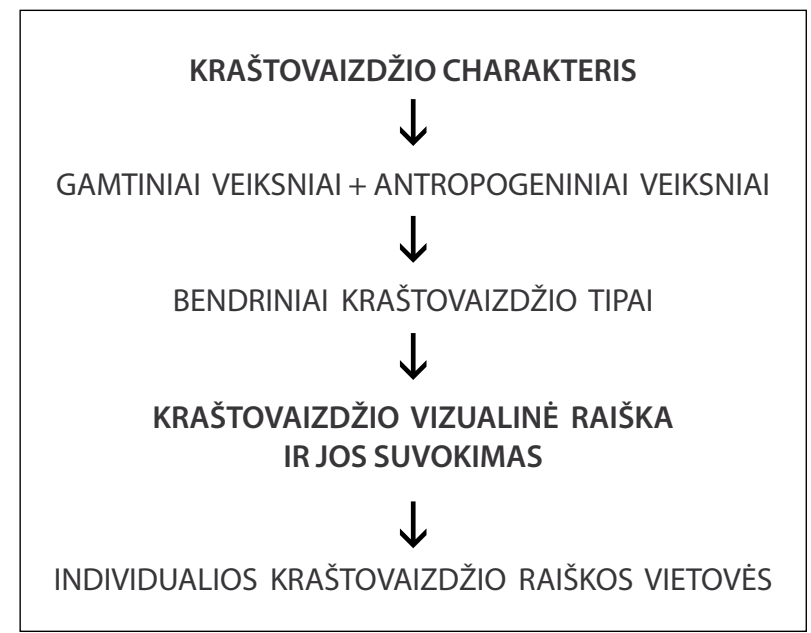

1 pav. Kraštovaizdžio charakterio struktūra

Fig. 1. Structure of landscape character gamtiniams ir kultūriniams kraštovaizdžio elementams ar jų deriniams priskiriamos estetinès reikšmès. Taigi subjektyviosios kraštovaizdžio vizualinès raiškos charakteristikos (gražu, harmoninga ir kt.) atitinka fizinius elementus, kurie ir yra teritorijų planavimo objektas. Konkretūs fiziniai urbanistinès plètros elementai gali išryškinti arba niveliuoti kraštovaizdžio vizualinès raiškos, o kartu ir kraštovaizdžio charakterio savitumą, unikalumą. Autore pritaria Kaimo charakterio reguliavimo tarnybos (Contryside... 2003) pateiktai kraštovaizdžio charakterio sampratai. Tai - savita, atpažistama ir darni kraštovaizdžio elementu visuma, kuri ne tiek vietovę daro geresnę ar blogesnę, kiek ja išskiria iš kitu vietovių. Iš esmès kraštovaizdžio charakteris yra tai, kas daro vietove unikalia, nepakartojama (1 ir 2 pav.).

\section{Kraštovaizdžio klasifikacijos pagal gamtinès raiškos potencialą metodas}

Kaip būtų galima vertinti kraštovaizdžio visumą ne vien jo kokybės aspektu (kaip dažniausiai yra daroma teorijoje ir praktikoje), bet kartu žvelgiant i kraštovaizdi kaip i suvokimo objektą? Kas kraštovaizdyje stimuliuoja žmogaus jausmus, pojūčius, kurie apibendrinami jo smegenyse ir galiausiai apibendrinami bei mentališkai išreiškiami abstrakčiomis kraštovaizdi apibūdinačiomis sąvokomis, pavyzdžiui, harmoningas, išraiškingas, vaizdingas kraštovaizdis? Tam galima pasitelkti Geštalto teoriją, kurioje nagrinëjama aplinkos suvokimo psichologija. Šios teorijos pagrindai susiformavo Vokietijoje XX a. pradžioje. Teorija remiasi koncepcija, pagal kurią visuma yra daugiau nei atskirų dalių suma (Kohler 1947, Lothian 2000). Ši koncepcija gali būti taikoma ir nagrinėjant kraštovaizdị, nes estetinis gerèjimasis kraštovaizdžiu išplaukia būtent iš jo visumos, kuri, kaip matyti iš ankstesnių samprotavimų, paaiškinama subjektyvistine kraštovaizdžio samprata, t. y. kraštovaizdžio visuma visų pirma būtų tai, kaip ją apibendrina ją suvokiantis žmogus. Remdamasi pagrindiniais Geštalto psichologijos dèsniais apie aplinkos visumą, autore iškelia hipotezę, kad skirtingas kraštovaizdžio gamtinių elementų, erdvių ar vaizdų

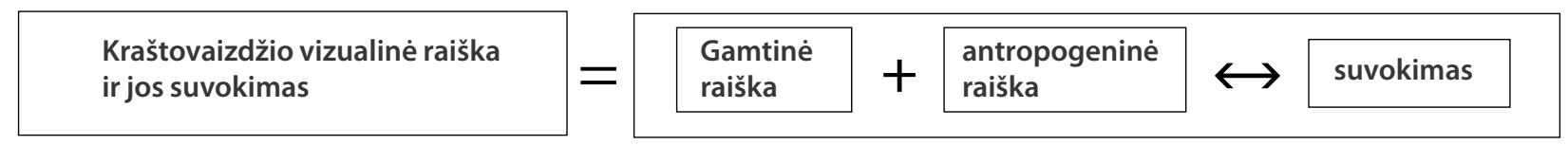

2 pav. Kraštovaizdžio vizualinè raiška

Fig. 2. Landscape visual expression 


\begin{tabular}{|c|c|c|c|}
\hline $\begin{array}{l}\text { Kraštovaizdžio } \\
\text { vizualinės raiškos } \\
\text { savitumo apsauga } \\
\text { didmiesčio } \\
\text { priemiestinèse } \\
\text { teritorijose }\end{array}$ & $\begin{array}{l}\text { Kraštovaizdžio viene- } \\
\text { tai pagal gamtinės } \\
\text { raiškos kompozicini } \\
\text { potencialą }\end{array}$ & $\Rightarrow \begin{array}{l}\text { Antropogeninių struktū- } \\
\text { rų integracija gamtinèje } \\
\text { kompozicijoje }\end{array}$ & $\begin{array}{l}\text { Pozityvus kraštovaizdžio suvokimas: } \\
\text { kraštovaizdžio reprezentatyvumas, } \\
\text { išraiškingumas, ivairovė, } \\
\text { individualumas }\end{array}$ \\
\hline
\end{tabular}

3 pav. Kraštovaizdžio vizualinès raiškos savitumas

Fig. 3. Individuality of landscape visual expression

vizualinès raiškos potencialas lemia skirtingą pirminị kraštovaizdžio visumos ịspūdị. Geštalto pagrindiniai dèsniai apie aplinkos visumą teigia (Wolman 1973, Lothian 2000):

- Visuma yra tai, kas svarbiausia ir kas suvokiama pirmiau, nei atskiros ją sudarančios dalys.

- Suvokti visumą ir ị ją reaguoti žmogui yra daug natūraliau ir lengviau, negu suvokti ir reaguoti $i$ atskiras šią visumą sudarančias dalis.

- Visuma pasižymi užbaigtumu, simetrija, paprastumu atsižvelgiant ị vyraujančias sąlygas.

- Visumą daugiau lemia vidiniai nei išoriniai veiksniai.

- Atskiros dalys igyja savo savybes priklausomai nuo jų padèties ar funkcijos visumoje.

Skirtingos topografijos teritorijose kraštovaizdis pasižymi skirtingo gamtinès raiškos kompozicijos potencialo vietovèmis. Atvirose vietovèse išryškèja reljefo formų charakteris. Vietovèse, pasižyminčiose atvirų ir uždarų plotų mozaikiškumu, ịdomu nagrinèti smulkesio mastelio gamtinių elementų ir erdvių santykị. Ryškiai išreikštuose reljefo struktūros perkirtimų zonose atsiveria nepertraukiamos gamtinès erdvès apžvalgos galimybè. Kontrastingo ir neišreikšto reljefo ribinèse zonose dažnai atsiveria fokusinio pobūdžio gamtiniai vaizdai ir kt. Visa tai ir lemia jau minètą skirtingą pirminị kraštovaizdžio visumos įspūdį. Taigi, remdamasi anksčiau išsakytomis mintimis, autore siūlo kraštovaizdžio vizualinę raišką klasifikuoti, atsižvelgiant i gamtinių elementų, erdvių ar vaizdų raiškos kompozicini potencialą. Tokia kraštovaizdžio vizualinès raišskos klasifikacija papildo bendrinių kraštovaizdžio tipų klasifikaciją gamtiniu požiūriu ir yra svarbi nustatant vietos reikšmę ir identitetą, reglamentuojant naujų antropogeninių darinių - daugiausia statinių - atsiradimą priemiestinių teritorijų kraštovaizdyje. Šiais laikais, kai urbanizacija ịgyja vis didesnį sklaidos mastą ir dinamiką, apsiriboti tik atskirų kraštovaizdžio elementų tyrinèjimu, jų tarpusavio ryšio nustatymu nepakanka. Būtina ieškoti būdų, kaip visa anksčiau surinkta informacija, t. y. kraštovaizdžio inventorizacija, galètų būti pritaiky- ta projektavimui. Pasak Marot, pagrindinis uždavinys planuojant kraštovaizdi yra išlaisvinti, atskleisti, sustiprinti, aiškiai artikuliuoti, moduliuoti vietos potencialą (Marot 1994).

Susiklosčiusią kraštovaizdžio vizualinès raiškos estetinių kriterijų grupę (mastelis, forma, linija, spalva, tekstūra ir pan.) autorẻ siūlo papildyti dar vienu, integraliu, kraštovaizdžio estetinès raiškos kriterijumi - užstatymo pozicija. Remiantis šiuo kriterijumi, nustatomas esamos kraštovaizdžio gamtinès raiškos ir naujai įtraukiamų antropogeninių darinių harmoningas santykis konkrečiose vietovèse. Siekiant išlaikyti harmoningą kraštovaizdžio vizualinès raiškos charakterị, pokyčiai turi būti minimalūs, ir iš pat pradžių orientuoti pagal dominuojanti gamtinès raiškos objektą - elementą, erdvę, vaizdą (3 pav.).

\section{Praktinis kraštovaizdžio klasifikacijos pagal gamtinès raiškos kompozicijos potencialą metodo taikymas (Trakų rajono pavyzdys)}

Aktyvejjant didmiesčio urbanistiniams procesams kraštovaizdžio charakteris tampa centriniu Trakų rajono dalies, patenkančios ị Vilniaus metropolinị arealą, vertinimo objektu, kuriame vizualiai atsispindi gamtinių ir antropogeninių elementų su jiems būdingomis morfologinèmis savybèmis tarpusavio sąveika. Jų kokybė rodo kraštovaizdžio charakterio ekologinio stabilumo ir estetinio patrauklumo potencialą (4 pav.).

Derinant kraštovaizdžio vizualinès raiškos savitumo apsaugą su užstatymo pletros keliama problematika nagrinejjamoje Vilniaus metropolinio arealo dalyje kraštovaizdžio vizualinę raišką siūloma klasifikuoti pagal jos gamtinès raiškos pagrindines kompozicines funkcijas - gamtinès raiškos potencialą. Remiantis šia klasifikacija diferencijuojamas vertingiausių kraštovaizdinių teritorijų tvarkymas ir naudojimas, taip pat reguliavimas urbanistinès plètros aspektu.

Remiantis kraštovaizdžio fiziniais, erdviniais bei vizualiniais kriterijais, sugriežtintos kraštovaizdžio vizualinès apsaugos zonoje išskiriamas kraštovaizdžio 
vizualinį identitetą formuojantis bei vizualinès raiškos savitumą lemiantis kraštovaizdžio gamtinès raiškos potencialas $(5,6$ pav.):

1. Kompozicinio potencialo kraštovaizdis (KPK-a, KPK-b, KPK-c).

2. Vidinio ekspozicinio potencialo kraštovaizdis (VEPK-a, VEPK -b).

3. Išorinio ekspozicinio potencialo kraštovaizdis (IEPK-a, IEPK-b).

4. Foninio potencialo kraštovaizdis (FPK-a, FPK-c). Sugriežtintos kraštovaizdžio vizualinès apsaugos zonoje papildomai ịvertinus kraštovaizdžio planinès ir erdvinès struktūros skaidą išskiriami kraštovaizdžio vizualinès raiškos jautrumo galimam sodybiniam užstatymui laipsniai: 0 - labai jautrus, 1 - jautrus, 2 - vidutiniškai jautrus, 3 - mažai jautrus, 4 - nejautrus. Remiantis kraštovaizdžio vizualinès raiškos jautrumu galimam sodybiniam užstatymui individualioms kraštovaizdžio tvarkymo zonoms nustatomas sodybinio užstatymo tankumas: 0 - ypač retas, 1 - retas, 2 - vidutiniškai retas, 3 - vidutiniškai tankus, 4 - tankus. Galimo sodybinio užstatymo tankumas ir intensyvu- mas sugriežtintos kraštovaizdžio vizualinès apsaugos zonoje nustatomas specialiuoju planu, įvertinant individualių kraštovaizdžio tvarkymo zonų struktūrinius ypatumus (kraštovaizdžio planinè ir erdvinè skaida), remiantis nustatytu sodybų tankumo formavimo laipsniškumu, atsižvelgiant ị gamtosauginius reikalavimus. Galimo sodybinio užstatymo aukštingumas ir pozicija kraštovaizdyje nustatoma specialiuoju planu, remiantis anksčiau nustatytomis atskirų kraštovaizdžio tipų gamtinès raiškos identitetą formuojančiomis kompozicinèmis savybėmis. Papildomai ịvertinamas kraštovaizdžio gamtinès raiškos objektų matomumas nuo turistinių trasų, vietovių.

\section{Išvados}

1. Lietuvos priemiesčių planavimo praktikoje pasigendama gamtinio kraštovaizdžio ir užstatymo integruoto plètros modelio. Tai iškelia kraštovaizdžio vizualinės raiškos vertinimo bei klasifikavimo ir integralios planavimo metodikos nustatymo būtinybę priemiesčių (metropolinių arealų) teritorijose. Šiuo

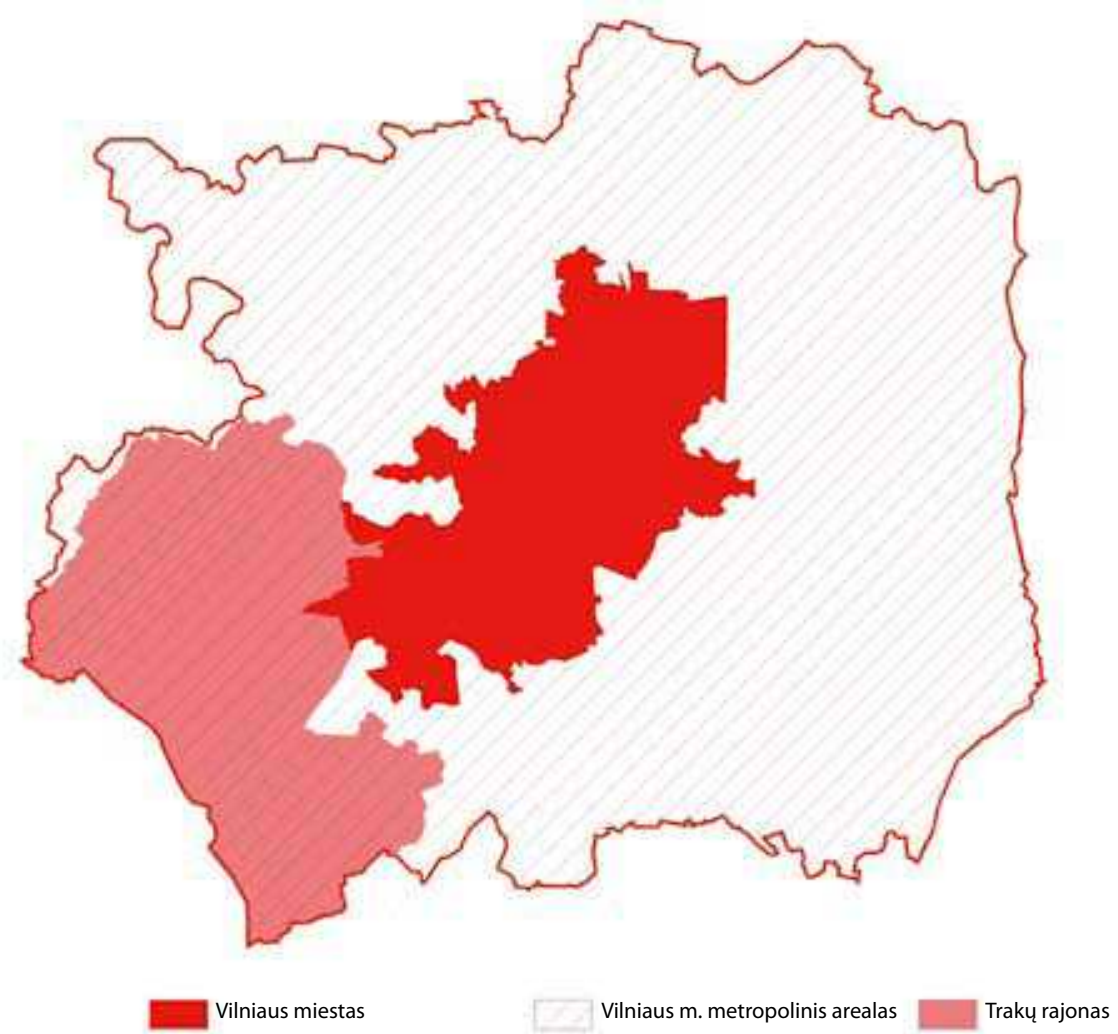

4 pav. Trakų rajonas Vilniaus metropoliniame areale

Fig. 4. Trakai district in the zone of Vilnius metropolis 


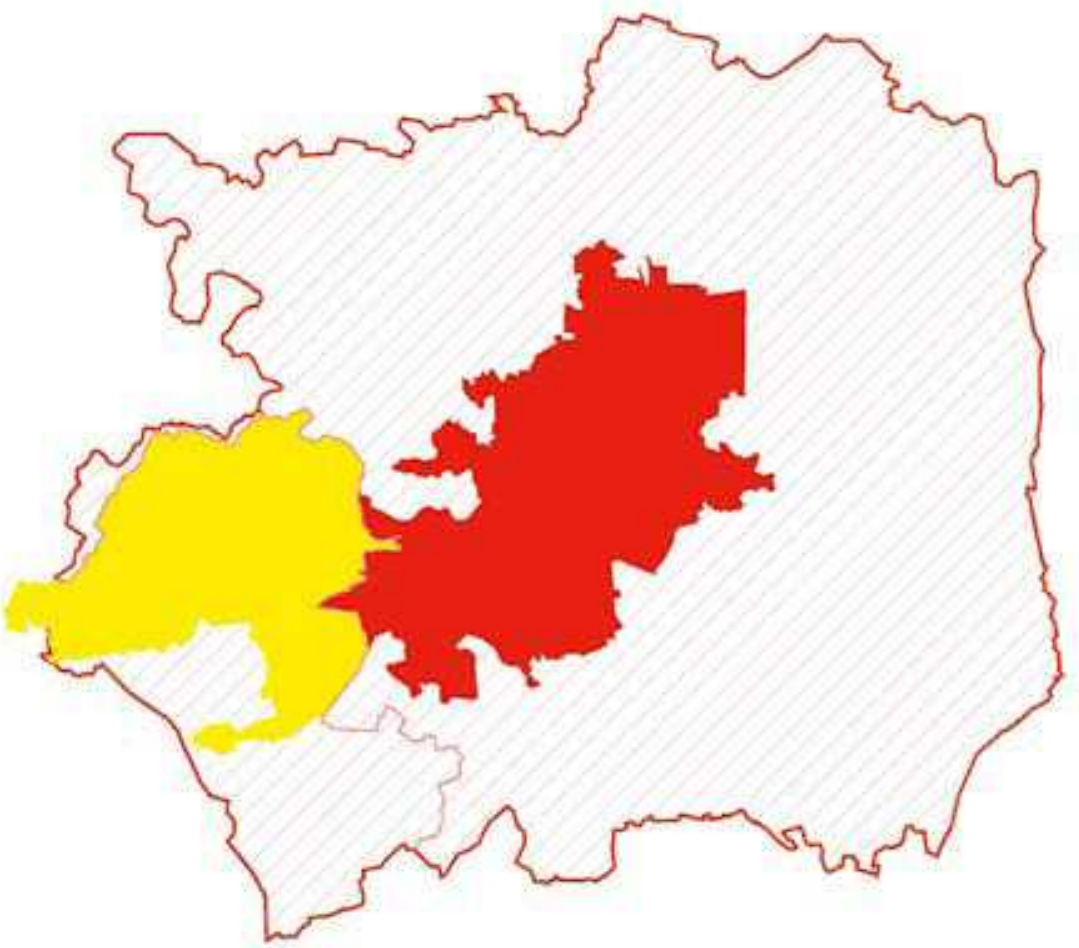

Vilniaus miestas

Vilniaus m. metropolinis arealas

Trakų rajonas

Sugriežtintos vizualinès apsaugos zona

5 pav. Sugriežtintos kraštovaizdžio vizualinės apsaugos zona

Fig. 5. Zone of strict visual landscape preservation

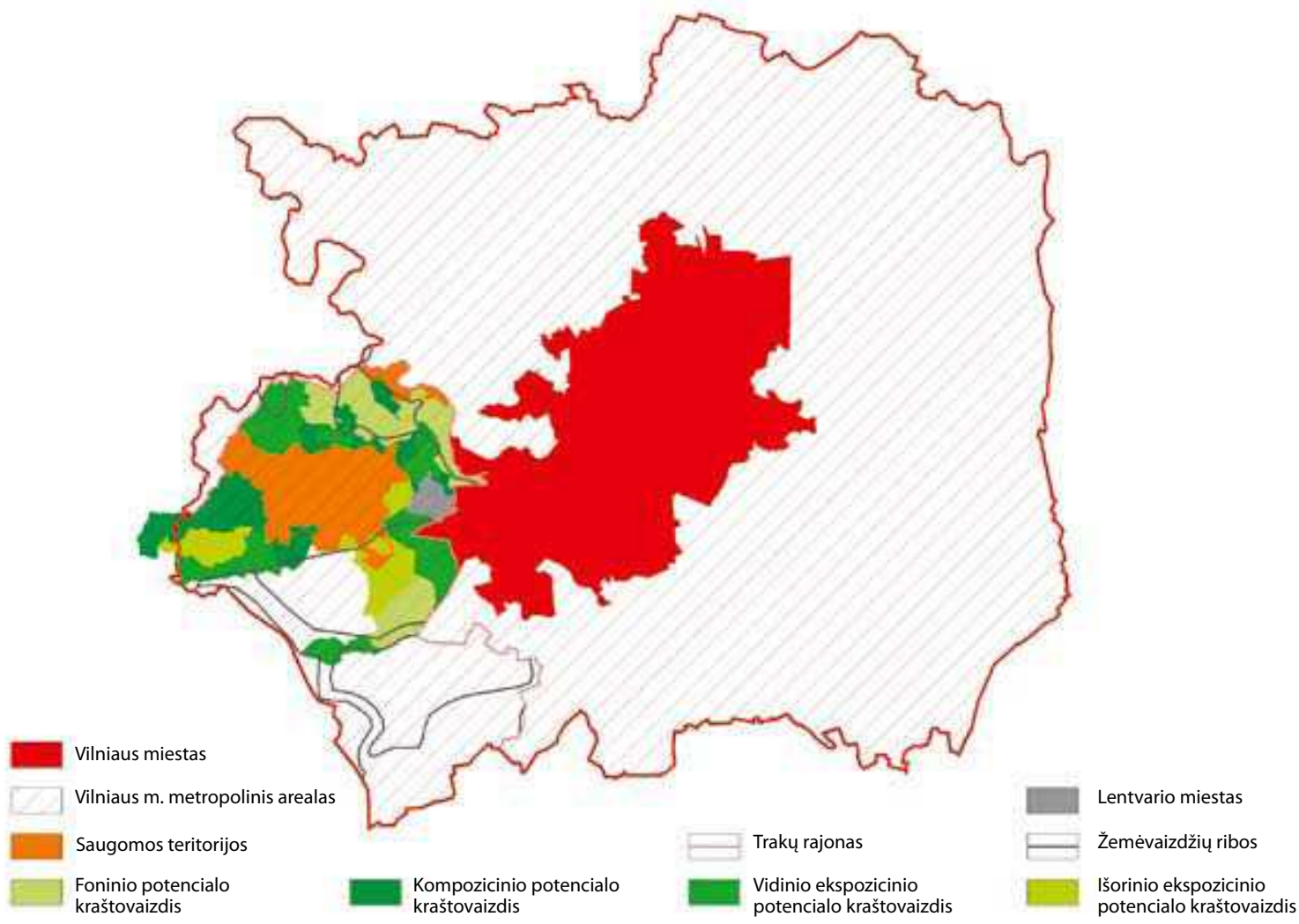

6 pav. Kraštovaizdžio vienetai pagal gamtinės raiškos kompozicijos potencialą

Fig. 6. Landscape types according to compositional potential of natural expression 
Kraštovaizdžio tvarkymas ir naudojimas sugriežtintos kraštovaizdžio vizualinės apsaugos zonoje Landscape management in the zone of strict visual landscape preservation

Kraštovaiz- Gamtinès raiškos identitetas
džio vienetai
pagal gam-
tinès raiškos
potencialą

\begin{tabular}{|c|c|c|}
\hline KPK-a & $\begin{array}{l}\text { Gamtini kraštovaizdžio savitumą ir j̧simintinu- } \\
\text { mą formuoja atviros kalvos, kalvagūbriai. }\end{array}$ & $\begin{array}{l}\text { Saugomas atvirų kalvụ bei atvirų kalvų bei ežerų derinių domi- } \\
\text { navimas kraštovaizdyje. }\end{array}$ \\
\hline KPK-b & $\begin{array}{l}\text { Gamtini kraštovaizdžio savitumą ir jisimintinu- } \\
\text { mą formuoja kompoziciniu požiūriu aktyvi te- } \\
\text { ritorijos padètis reljefo erdvinèje struktūroje. }\end{array}$ & $\begin{array}{l}\text { Saugomas viršutinès šlaito briaunos ir artimiausių teritoriju } \\
\text { gamtinio charakterio dominavimas kraštovaizdyje. }\end{array}$ \\
\hline KPK-c & $\begin{array}{l}\text { Gamtini kraštovaizdžio savitumą ir ịsimintinu- } \\
\text { mą formuoja kalvotas reljefas. }\end{array}$ & Saugomi atvirų kalvų pikai. \\
\hline VEPK-a & $\begin{array}{l}\text { Gamtini kraštovaizdžio savitumą ir j̧simintinu- } \\
\text { mą formuoja gamtinis kompleksas, pasižymin- } \\
\text { tis vientisu vizualiniu suvokimu. }\end{array}$ & Saugomas gamtinio komplekso dominavimas kraštovaizdyje. \\
\hline VEPK-b & $\begin{array}{l}\text { Gamtini kraštovaizdžio savitumą ir įsiminti- } \\
\text { numą formuoja mišku ir atviru plotų vertika- } \\
\text { lios ir horizontalios foninès plokštumos. }\end{array}$ & $\begin{array}{l}\text { Saugomas vizualines vietoves - erdves ribojančiu elementu } \\
\text { gamtinio charakterio dominavimas kraštovaizdyje. }\end{array}$ \\
\hline IEPK-a & $\begin{array}{l}\text { Atviru plotu, foninio kraštovaizdžio poten- } \\
\text { cialo bruožais pasižyminčio kraštovaizdžio } \\
\text { savitumą ir i̇simintinumą formuoja atsive- } \\
\text { riantys gamtiniai vaizdai. }\end{array}$ & $\begin{array}{l}\text { Saugomi vertingiausi ekspoziciniai taškai, ruožai, } \\
\text { zonos, iš kurių atsiveria didžiausiu kompoziciniu } \\
\text { potencialu pasižymintys gamtiniai objektai. }\end{array}$ \\
\hline IEPK-b & $\begin{array}{l}\text { Atvirų plotŭ, foninio kraštovaizdžio poten- } \\
\text { cialo bruožais pasižyminčio kraštovaizdžio } \\
\text { savitumą ir jisimintinumą formuoja atsive- } \\
\text { riantys kultūriniai vaizdai. }\end{array}$ & $\begin{array}{l}\text { Saugomi vertingiausi ekspoziciniai taškai, ruožai, } \\
\text { zonos, iš kurių atsiveria kultūrinis objektas bei jo ir aptariamos } \\
\text { teritorijos gamtinių foninių plokštumų (miškų, atvirų plotų) } \\
\text { kompoziciniai ryšiai. }\end{array}$ \\
\hline FPK-a & $\begin{array}{l}\text { Gamtini kraštovaizdžio savitumą ir isimin- } \\
\text { tinumą formuoja vertikalios foninès mišku } \\
\text { plokštumos. }\end{array}$ & $\begin{array}{l}\text { Saugomas uždaru erdvių - miško dominavimas } \\
\text { kraštovaizdyje. }\end{array}$ \\
\hline
\end{tabular}

FPK-c Gamtini kraštovaizdžio savitumą ir įsimintinumą formuoja atvirų plotų horizontalios foninès plokštumos.
Gamtinès raiškos identiteto išsaugojimas reguliuojant užstatymo poziciją kraštovaizdžio gamtinès raiškos elementu, erdvių bei atsiveriančių vaizdų atžvilgiu 
spalva, tekstūra ir pan.) tikslinga papildyti kraštovaizdžio estetinès raiškos kriterijumi - užstatymo pozicija. Remiantis šiuo kriterijumi, papildomai atsižvelgiama ị konkretaus kraštovaizdžio tipo planinę bei erdvinę skaidą - mastelị. Taip užtikrinamas esamos kraštovaizdžio gamtinès raiškos ir naujai atsirandančių antropogeninių darinių harmoningas santykis konkrečiose vietovese.

5. Vientisas kraštovaizdžio gamtinès raiškos ir užstatymo planavimo modelis pirmiausia taikytinas didmiesčio priemiestinių teritorijų probleminèms situacijoms (pavyzdžiui, Trakų rajone), atliekant jų bendrąji arba specialujji planavimą.

\section{Literatūra}

Ahern, J. 1995. Greenways as a planning strategy, Landscape and Urban Planning 33: 131-155.

Antrop, M. 1997. The concept of traditional landscapes as a base for landscape evaluation and planning. The example of Flanders Region, Landscape and Urban Planning 38: 105-117.

Antrop, M. 2000. Background concepts for integrated landscape analysis, Agriculture, Ecosystems and Environment 77(1/2): 17-28.

Cambridge Green Belt Study: a Vision of the Future for Cambridge in its Green Belt Setting. Final Report. 2002.

Cambridge International Dictionary of English. 1995. Cambridge University Press, London.

Countryside Character Network. 2003.

Daniel, T. C., and Vining, J. 1983. Methodological issues in the assessment of landscape quality, in Behaviour and the Natural Environment. I. Altman, and J. F. Wohlwill (eds.). Plenum: N. Y., 39-83.

Devinduonis, R.; Šimukonytė, V.; Pilkauskas, R.; Šimkūnienė, V. 1980. Vilniaus miesto priemiestine zona. Esama padetis su gamtiniu salygu ivertinimu.

Fisher, J. D.; Bell, P. A., and Baum, A. (eds.). 1984. Environmental Psychology 2, N. Y.: Holt, Rinehart and Winston.

Jakaitis, J. 2001. Vilniaus miesto bendrojo ir operatyviojo planavimo patirtis integruotai plètojant miesto struktūrą ir gretimas teritorijas, Urbanistika ir architektūra 25(4): 190-195.

Juškevičius, P. 2007. Urbanistinès plètros peripetijos, Urbanistika ir architektūra 31(4).

Kaplan, R., and Kaplan, S. 1989. The experience of nature: A psychological perspective. N. Y.: Cambridge University Press.

Knopf, Richard C. 1987. Human behavior, cognition, and affect in the natural environment, Handbook of Environmental Psychology I. Edited by Daniel Stokols, John Wikyt Sons, Irwin Altman.

Kohler, W. 1947. Gestalt psychology: an Introduction to New Concepts in Modern Psychology. Liveright Publishing Co., N. Y.
Krause, Ch. L. 2001. Our visual landscape: Managing the landscape under special consideration of visual aspects, Landscape and Urban Planning 54: 239-254.

Landscape Assessment of County Leitrim. 2002. Technical Report.

Landscape Character Assessment in Ireland: Baseline Audit and Evaluation. 2006.

Landscape Character Assessment. Guidance for England and Scotland. 2002. The Countryside Agency and Scottish Natural Heritage.

Lynch, K. 1960. The image oh the City. Cambridge.

Lothian, A. 2000. Landscape Quality Assessment of South Australia. Dissertation for Doctorate of Philosophy. Department of Geographical and Environmental Studies. University of Adelaide.

LR kraštovaizdžio erdvinès struktūros ịvairovès ir jos tipų identifikavimo studija. 2006. Mokslinio darbo vadovas P. Kavaliauskas.

LR kraštovaizdžio politikos krypčių aprašas, patvirtintas LR Vyriausybės $2004 \mathrm{~m}$. gruodžio $1 \mathrm{~d}$. nutarimu Nr. 1526 (Žin., 2004, 174 - 6443; 2005, Nr. 64 - 2302).

Marot, S. 1994. On public space as landscape. Landscape Architecture in France, Archis Journal. Architecture, urbanism, visual arts. Nai, Rotterdam.

Meyer, Elizabeth K. 2000. The Post-Earth Day Conundrum: Translating Environmental Values into Landscape Design, in Environmentalism in Landscape Architecture. Edited by Michel Conan. Published by Dumbarton Oaks Research Library and Collection Washington, D. C. 22.

Oxford Advanced Learner's Dictionary. 2005. Seventh edition. Oxford University Press.

Oxford American Dictionary. 1980. Oxford University Press. Oxford, N. Y.

Palmer, J. 2003. Research Agenda for Landscape Perception, in Buhmann, E.; Ervin, S. M. [Hrsg.]. Trends in Landscape Modelling, Proceedings at Anhalt University of Applied Sciences.

Punter, J.; Carmona, M. 1997. The Design Dimension of Planning: Theory, Content and the Best Practice for Design Policies. London, E/FN.

Smith, T. 1997. Quality of an urban community: a framework for understanding the relationship between quality and physical form, Landscape and Urban Planning 39: 229-241.

The European Landscape Convention. Lorence. 2000.

The LANDMAP Information System. Countryside Council for Wales. 2001.

The Oxford Illustrated Dictionary. 1962. Oxford at the Clarendon Press.

The Oxford Modern English Dictionary for Everyday Use. 1992. Oxford University Press, N. Y.

Tiškus, G. 2007. Urbanistinès plètros valstybinio valdymo problemos, Urbanistika ir architektūra 31, 4.

Vanagas, J. 1991. Didysis Vilnius: urbanistinès prognozès, Statyba ir architektūra, 7.

Vroom, J. Meto. 2006. Lexicon of Garden and Landscape Architecture. 
Wolman, B. B. 1973. Handbook of general psychology. PrenticeHall, Inc, New Jersey.

Яргина, 3. Н. 1991. Эстетика города. Москва: Стройиздат. $365 \mathrm{c}$.

\section{PRESERVATION OF LANDSCAPE VISUAL EXPRESSION IDENTITY IN PERI-URBAN AREAS OF METROPOLIS}

\section{G. I. Laukaitytė-Malžinskienè}

Abstract. In the context of urban expansion the preservation of the individuality of landscape visual expression in peri-urban areas is becoming a very relevant but at the same time hard task. Practice of landscape planning is commonly confined to general physical or visible landscape characteristics and their description. Urban development in peri-urban areas is usually confined to functional or structural planning criteria. Thereby, the Lithuanian theory and practise of territory planning really needs a method of landscape and urban development which leads to an the integrated landscape assessment and planning, based on physical, visible and mainly individually perceived features of landscape visual expression.

Keywords: urban development, peri-urban areas, landscape character, sensitivity, perception and visual expression.

\section{GIEDRE் I. LAUKAITYTE்-MALŽINSKIENE்}

Master, extramural doctoral student, Dept of Urban Design, Vilnius Gediminas Technical University (VGTU), Pylimo g. 26/ Traku g. 1, LT-01132 Vilnius, Lithuania.

E-mail: laukaitytegiedre@hotmail.com

Master of Architecture, VGTU, 2000. Publications: co-author of two and author of one research papers in the journal Town Planning and Architecture (Urbanistika ir Architektūra), co-author of three research works. Research interests : landscape planning, landscape design. 